Kevin Inston

School of European Languages Cultures and Society

UCL

1-4 Malet Place

London WC1E 6BT

k.inston@ucl.ac.uk 


\begin{abstract}
Recent theories of community (Nancy, Agamben, Esposito) aim to think the term beyond its definition as the ownership of shared identity, language, culture or territory. For Esposito, to reduce community to a property whose possession distinguishes members from non-members undermines the commonality the term implies. The common opposes what is proper or one's own; it belongs to everyone and anyone. Rather than securing identity and belonging, community, defined by its impropriety, disrupts them so that we are in common. While his work successfully illustrates the incompatibility of the common and the proper, it leaves unanswered the question of how communities come to experience their impropriety. Through a comparison with Rancière's improper community, we can identify and gesture beyond this limit. Its members intervene in proper communities by exercising the right to decide on common matters despite officially having no right to do so. Their actions, by demonstrating the openness of the common to anyone and everyone, turn its privatisation into a shared wrong that connects community with non-community. By supplementing Esposito's work with Rancière's, we see how communities relate to what they have deemed improper in a way that both challenges and revitalises their sense of commonality.
\end{abstract}

Key words: Esposito; Rancière; Community; Immunity; Impropriety; the proper. 


\section{Improper communities in the work of Roberto Esposito and Jacques Rancière}

Can we think a mode of community that is not based on the ownership of a shared identity, ethnicity, culture or territory? A community that is not proper to those it includes and improper to those it excludes? Can it be thought in a truly inclusive and open form that challenges its often divisive and exclusionary realisation? These questions have motivated recent work in French and Italian political philosophy which argues that a proprietary conception of community ultimately defeats itself (Nancy, 1991, 1992, 2000; Agamben, 1993; Esposito, 2010). ${ }^{1}$ To reduce community to a specific property which its members appropriate to the exclusion of others is to undermine the sense of commonality that the term implies (Esposito, 2010, pp. 1-19, 135-149). If community can be enclosed and possessed, it is no longer common or shared. To imagine it as a state of oneness is to negate its relational dimension: to be one is not to be with. Despite these contradictions, the idea that an authentic or proper community can be achieved or recovered by excluding what is deemed inauthentic or improper to it still resonates. This self-contradictory process of excluding to unify always backfires, producing a remainder that frustrates its aim of communal purity (Nancy, 1991, pp. 12-16). The pursuit of proper community therefore causes insecurity and violence rather than stability and peace. Against this background, theories of improper community - one defined by the absence of any exclusive property - have emerged.

If the term community is so closely associated with identarian movements, we may question why we retain it (Derrida, 1995, p. 46). However, to abandon it would deny its potential for resignification and would allow such movements to appropriate its meaning entirely. For this reason, Jean-Luc Nancy rethinks community beyond figures of identity and totality, conceiving it as an ontological being-in-common as opposed to a self-enclosed common being (Nancy, 1991, pp. xxxvi-xli, 1-42; Nancy, 2000, pp. 10-47). His work initiated several important philosophical interventions into the question of community which 
aim to liberate the term from its identarian connotations. Among them is Roberto Esposito's theory of communitas which convincingly underlines the philosophical and political incompatibility of the common and the proper. Community, he argues, is defined by its resistance to any proper or authentic form, by its refusal of identity and belonging, by its impropriety. Esposito follows Nancy in not conceiving community as something we have in common but what is in common. ${ }^{2}$ It is the condition of our being in the world. We cannot exist without the limits of others which define us by exposing us to what we are not. What is proper to us - our singular being - is also improper because its sense depends on otherness and plurality, on not being wholly our own (Nancy, 2000; Esposito, 2010). Esposito extrapolates more explicit political and ethical consequences from Nancy's ontology. If we are in common on the condition that we are not self-sufficient, community does not fulfil us but leaves us lacking to the extent that we become indebted towards others, obliged to perform common duties.

Despite this emphasis on duty, the fact that community, as the condition of existence, cannot be realised through collective action questions what kind of politics Esposito's theory affirms. ${ }^{3}$ While his work argues that the communitarian ontology obliges us to resist attempts to privatise the common, it says little about how that resistance occurs, how proper communities begin to relate to what they have judged improper. For this reason, I shall supplement Esposito's theory with Rancière's conception of 'improper community' (Rancière, 1999, p. 137). ${ }^{4}$ That conception distances itself from ontological theories, understanding it as a historical event arising when those not counted as equal make themselves count. Its members intervene in the proper community by exercising the right to decide on common matters despite having no right to do so. Whereas Esposito and Rancière both deconstruct the proper/improper opposition, they inflect the idea of impropriety slightly differently. Esposito broadly uses it in terms of the Latin proprius (one's own) to designate 
what it is other and more specifically the lack of common property which enables the being with of community. Rancière employs it to designate a paradoxical state of belonging to two communities at once: that of the part without part and the one of equal parts (p. 137). However, as Davide Panagia has shown, impropriety also assumes a meaning closer to its modern English sense, designating ways of speaking and acting which dismantle the rules of propriety governing how groups are expected to behave within a social hierarchy (Panagia, 2009, 2018). ${ }^{5}$ This meaning stresses the focus on action for Rancière. Impropriety is not a transcendental condition, as it is for Esposito, but is politically produced in opposition to a community's criteria of adherence. Notwithstanding this difference, their theories of improper community converge in not simply inverting its proprietary conception, if they did, they would risk repeating in a negative form the logic they question. Rather they show how no community can fully immunise itself against what it believes other to its identity or values and how that non-closure, rather than threatening it, can revitalise its sense of the common by affirming its potential to relate to otherness. Despite their shared goal, Rancière's work goes further, I maintain, in demonstrating how this process could occur in practice.

Rancière's rejection of an ontological approach shifts the focus of debates about community from theory to praxis, exploring how political action could challenge the proprietary logic, which, for Esposito, dominates modernity. His account of improper community therefore goes some way to answering a question raised but never fully addressed by Esposito's philosophy. However, his refusal of ontology, of explicitly theorising what community is, leaves his work less equipped than Esposito's to explain why a proprietary conception of community contradicts itself and why it should be rethought in terms of impropriety. Framing Rancière's politics, as the (ac)count of those not counted by communities, with Esposito's ontology lends it, I argue, renewed significance as a striking alternative to mainstream philosophy and politics of community. 
I begin by analysing Esposito's theory of communitas which calls for the invention of common spaces, dimensions and spheres to interrupt the exclusionary practices paradoxically used by communities to forge commonality. However, it risks, I argue, presenting modernity as so dominated by the proprietary logic that it offers little scope for imagining how the openness of the common could ever be sensed and acted upon to disrupt it. I then focus on Rancière's account of improper community as a response to this impasse. Improper communities act to redistribute who is seen and heard so that the equal share of all in the common, which, for Rancière, is a supposition in constant need of testing and, for Esposito, the ontological condition of existence, becomes perceptible within social orders always based on unequal shares. This process occurs through the dissensual practices of appropriation, disidentification, and subjectification, identified by Claire Woodford as constituent moments of Ranciere's politics (Woodford, 2017, pp. 31-60). Those practices form the strategy used by subjects to break into a community that has excluded them, to re-open the common. The duty affirmed by Esposito's communitas can be understood via Rancière's work as the willingness to live beyond state-imposed restrictions as if community always already includes everyone and anyone. This process of testing the openness of community through action is essential for demonstrating the contingency of those restrictions and their susceptibility to alteration by what they exclude, for obliging others to see a shared world between community and noncommunity.

\section{Esposito's communitas}

For Esposito, community conceived as a common property always functions to divide and exclude rather than unify and include. It annuls the idea of community for "what is common is the exact contrary of one's own; common is what is not one's own, or what is unable to be appropriated by someone.' It belongs to all and therefore cannot belong to anyone in particular. However, despite its self-cancelling logic, the proprietary conception of 
community, Esposito maintains, has dominated modern thinking. 'Both American neocommunitarians and organistic German sociology' understand community as 'belonging, identity and ownership', 'as something that identifies someone with his/her own ethnic group, land and language' (Esposito, 2013b, p. 48). ${ }^{6}$ They link community to the semantics of property both in the sense of a quality that defines members as belonging to a single totality and as a possession that each member owns. Understanding community in this way has distorted or even perverted its meaning (Esposito, 2010, p. 1). Esposito's work deconstructs this process of appropriating the common to define community through an etymological analysis of the Latin term communitas. communitas combines cum (with) and munus, a complex bivalent term, denoting "a "task" "duty", or "law" and "“a gift" [...] which is to be given rather than received' (Esposito, 2013b, p. 15). These two dimensions of communitas converge in a common obligation which requires members to renounce their 'most precious substance, namely their individual identity, in a process of gradual opening from self to other' (Esposito, 2013a, p. 84). Esposito calls this obligation the law of community, not to be understood as 'an external injunction' but as 'something more inherent': we need community to exist (Esposito, 2013b, p. 14). Any being exists only if it is exposed to an outside, requiring something other than itself to grasp what it is. Existence is necessarily coexistence.

Community, being ontologically always already there, does not therefore arise from the unification of disparate individuals into a collective subject, as dominant theories believe. The communitarians, for example, Esposito maintains, simply 'apply' 'the subjectivist and individualistic lexicon' of 'their alleged adversaries the liberals' to community, conceiving it as an enlarged version of the liberal subject that they aim to oppose (Esposito, 2013b, p. 38). ${ }^{7}$ Esposito's insistence on munus, as duty and gift towards others, however, challenges that subject concerned with the protection of individual rights and (self)-ownership. It joins us in an act of giving, for each of us owes to others the sense of existence. Far from identifying 
someone with an ethnicity, culture, and place, community, as 'the loss of the proper', is 'the interval of difference, the spacing that brings us into relation with others in a common nonbelonging' (Esposito, 2010, p. 139). It is not something that we have in common but is the no-thing, the space in-between that allows or rather obliges us to be in common. Community should therefore enjoin us to resist, rather than engage in, political projects that aim to construct it as a property whose possession distinguishes members from non-members. If modernity is as dominated by the proprietary logic as Esposito insists, the question of how we begin to sense that injunction becomes pressing.

Esposito never directly addresses it, preferring to explore the ambiguities surrounding any politics of community. We can neither realise it for 'it precedes every possible realisation' nor can we constitute it for it 'already constitutes us' (Esposito, 2013b, p. 16). Community proves 'impolitical' in that political action can never produce it as an object (Esposito, 2010, p. 97). Impolitical does not, however, mean unpolitical, indicating how being-in-common resides simultaneously within and beyond politics as the question which both initiates and exceeds it. This constitutive impossibility leaves us to 'inhabit the narrow margin between what we owe and what we can do' (p. 15). What we owe, for Esposito, is clear. We share the lack of community in any presentable form; that lack also divides us raising the question of not whether we relate to one another but how we relate. What is less clear is what we can do.

This ambiguity comes from the fact that Esposito focuses primarily on the aporia that frustrates our attempts to realise community as a self-contained whole. This quest for closure always undermines itself, generating anxiety towards the outside which becomes blamed for the lack of wholeness. Community remains ontologically unfinished, and thus 'utterly incapable of producing effects of commonality, of association [accomunamento], and of communion. It doesn't keep us warm, and it doesn't protect us' (Esposito, 2010, p. 140). On 
the one hand, it opens us to what we are not as the defining contours of what we are. On the other, by exposing us to otherness, it leaves us vulnerable to violation from without. Community represents openness to a vital but also potentially threatening outside. It enables growth, alteration and redefinition only by disturbing the security of borders established to demarcate identity and belonging. While insisting that the politics of community occurs in the margin between debt and capacity, between respecting the alterity of communitas and remaining responsive to its uncertainty and risks, his work, I maintain, emphasises debt over capacity. In short, it elucidates more what we cannot do than what we can do to experience the in-common.

\section{Immunitas}

Esposito, for his part, believes that the shift in focus from the cum of communitas in Nancy's theory to munus transforms community from a passive state of being with to an active one of giving, allowing him to think through the transition from the ontological to the ontic (Esposito, 2013a, p. 84). ${ }^{8}$ Key to that transition is the paradigm of immunity understood as the 'tendency to protect life from risks that inhere in the relationship among men and women even at the cost of ending communitarian bonds' (Esposito, 2013a, p. 71). ${ }^{9}$ Despite being the negative modality of community, immunitas supplies the model for its modern conception and realisation. The predominance of immunitas over communitas prompts Esposito to call for their rebalancing. However, he never fully explains how it could occur, analysing instead the ethico-political implication of their interdependence (Esposito, 2011, p. 9).

Immunitas is defined negatively in relation to munus. If communitas 'binds its members in a commitment of giving from one to the other', 'immunitas by contrast [...] exonerates from this responsibility' (Esposito, 2013a, p. 84). This recalls both its legal sense (if someone has immunity, she is exempt from common law or the jurisdiction governing all 
other citizens), and its biological one (the way the body, through antibodies, withstands infection from external virus). 'By overlaying the legal and the medical semantic fields, one may well conclude that if community breaks down the barriers of individual identity, immunity is the way to rebuild them, in defensive and offensive forms, against any external element that threatens it' (Esposito, 2013a, p. 85). These imbricated meanings emerge in communities' attempts to preserve themselves by imposing borders to protect their property from outsiders. Like medical immunisation, the external threat becomes internal to the defence mechanism: the community internalises what it excludes to define itself. While individual and collective life necessitates an immune system, that system attacks itself when excessively 'exclusive and exclusionary toward all other human and environmental alterities', destroying the outside which enables growth, self-definition and redefinition (p. 86). ${ }^{10}$ This autoimmune logic defines negative biopolitics ${ }^{11}$, for Esposito, which occurs when the protection of life reverses into its destruction, when communities erect barriers that endanger their preservation more than the threat they forestall. ${ }^{12}$

Immunity, essential for preserving life, actually constrains or jeopardises it not only by limiting freedom through controls and borders but also by denying 'the opening of existence outside itself that takes the name of communitas' (Esposito, 2013a, p. 85). This aporia should not, Esposito asserts, cause resignation before conflict, exclusion and violence but actually ground our responsibility for distinguishing those mechanisms 'that facilitate our individual and collective experience' from those that 'diminish its vital power' (Esposito, 2013a, p. 88). This distinction will help identify the immunitary measures from which we should withdraw. However, withdrawal is not enough to develop an affirmative biopolitics that incorporates otherness not only to suppress it to protect sameness but to promote a sense of life in common. For Esposito, we need to rebalance the power between communitas and immunitas by creating common spaces, spheres and dimensions that force open the 
immunitary borders. Preventing self-destructive immunisation therefore involves uncoupling the common and the proper so that immunisation acts as a 'relational filter for' the outside (Esposito, 2013b, p. 88). ${ }^{13}$

\section{The Common}

Esposito's insistence on the common as the horizon of an affirmative biopolitics offers an 'alternative perspective' to the public/private division that 'shackles most political thought' (Bird \&Short, 2013b, p.10). That division follows the proprietary logic which negates communitas. Public denotes what belongs to the state while private designates what belongs to individuals. Public is thus not synonymous with the common which transcends belonging. The objective is not, however, entirely to abandon public spaces, which could facilitate rather than interrupt the privatising process of neoliberal globalisation which seeks to dissolve the boundary between public and private. ${ }^{14}$ The challenge resides on a more fundamental level, in our ability even to conceive the common whose improper character 'remains largely unknown, and even refractory, to our conceptual categories, which have long been organised by the immune dispositif' (Esposito, 2013a, p. 89). The development of an affirmative biopolitics depends on 'our capacity, even before acting, to think within this horizon, to think around and even from within the common' (p. 90).

Esposito concentrates more, as I have argued, on what thwarts rather than enables that capacity. It is restricted by the fact that the freedom necessary to challenge the immunitary paradigm is conceived from within that paradigm. Imagining an emancipatory mode of community would involve, Esposito argues, liberating 'freedom from liberalism and community from communitarianism' (Esposito, 2013b, p. 55). Despite their differences, both schools think freedom from a subjectivist viewpoint as 'a quality, a faculty, or a good that a collective subject or many subjects must acquire' (p. 50). Individuals or communities need to 
appropriate freedom to become proprietors of themselves to defend against external interference. The original meaning of freedom, like that of community, has therefore been perverted. Far from denoting the contraction of ownership, 'its Indo-European root leuth, or ledh (from which the Greek eleutheria and the Latin libertas derive), and the Sanskrit root frya (the source of the English freedom and German Freiheit) recall something that has to do with a common growth' (p. 51). Its 'communitarian' connotations are reinforced by etymological roots in 'love (lieben, life, love but perhaps also libet and libido) and 'affect and friendship (friend, Freund)'. This etymological analysis refutes it liberal negative definition 'as the absence of an impediment and the removal of a constraint' to affirm its 'connective, aggregating, unifying power' (p. 52). Freedom, far from immunising us against the contagion of others interrupts that process by disclosing the no-thing which frees us to exist as such without being forced to become something in particular.

Reconnecting freedom with this sense therefore becomes essential for developing our capacity to think within the horizon of the common. Despite reworking the political and philosophical categories which stymie that capacity, Esposito says little about how it could begin to prove itself in practice. ${ }^{15}$ His philosophy reaches, I maintain, deadlock. We need to think the common to break the hold of the proprietary community but to do so, that hold already needs to be broken because it is the reason why the common appears so unthinkable in the first place. This deadlock is tightened by his subtractive understanding of community. The need to create common spaces implies that they do not currently exist and would have to be added to the world even if their addition would entail withdrawal from possessive modes of thinking and acting. It would require a change of perception so that we would see and treat the world in less appropriative ways. It is unclear, however, how the subtractive force of communitas could also be generative. Rancière's theory of improper community could supplement Esposito's here. It conceives community as an inventive act that redistributes the 
sensory organisation of communities so that those not heard or seen as counting politically make themselves count. For Rancière, it is not about aiming to think the common and then acting but rather about acting in a way that produces or reshapes the common.

\section{Rancière's De-ontolgised Account of Improper Community}

For Rancière, the improper community is not an ontological condition but a manifestation of politics itself, understood as the verification in time and space of the equality of anyone and everyone which undercuts attempts to fix the criteria for inclusion in community. ${ }^{16}$ Tracing politics back to ontological principles risks, Rancière asserts, dissolving it altogether, allowing the ontology to 'take over [its] work' (Rancière, 2011, p. 12; Chambers, p. 19). He thus refutes the grounding of community either in a human property or Nancy's being-incommon: despite substantial differences, both approaches, he believes, 'think politics in terms of community' and community from the viewpoint of 'a property or an originary disposition to the common' (Rancière \& Noudelmann, 2003, pp. 87-88). They thereby overlook how the in-common is not immediately political, requiring subjects to politicise it by including themselves as equals in a community that has excluded them, how it gets perceived and shaped only through disputes over the existence of a shared world. ${ }^{17}$ In this sense, there is no ontological community, for Ranciere: it emerges through and after politics. Politics is tasked with inventing forms of community which disturb the self-evidence and propriety of existing ones. To make it serve an ontological end would deny its inventiveness.

Ranciere's rejection of ontopolitical theory would appear to oppose his work to Esposito's and to question my attempt to use it to elucidate the kind of politics communitas might entail. Whereas Esposito understands his communitarian ontology as impolitical rather than political, resistance would still seem, Rancière would argue, ontologically programmed insofar as any ontic community would eventually encounter finitude whether subjects 
intervene or not. His concern that ontologists allow their ontologies to highjack the role of politics usefully underlines the scant attention to political strategy and practice among thinkers such as Esposito and Nancy but overstates their faith in ontology. They reconceive community as the condition of existence not to displace politics but to call for its radical rethinking by revealing what enables but also transcends it. As I have already argued, Esposito remains vague on what an alternative politics of community would involve. Rancière's politics as the affirmation of 'the power of anyone' to contest any division of the common could be interpreted as responding to that call, allowing us to imagine how the borders of communities get redrawn to include what is judged improper to them (Rancière, 2009, p. 118).

Rancière's vehement refusal of ontology, Chambers (2013, p. 21) avers, comes from his commitment to studying politics in history, to understanding the methods used to thwart the privatisation of the common. Instead of providing a theory of community, he therefore attends to its polemical and historical event, to moments when improper communities declare their existence, disclosing the miscount on which the so-called proper count of community rests. Whereas Esposito queries whether we have the capacity to think the common let alone act in its name, Rancière's work records those moments when that capacity is verified by those thought incapable of it. Its historicity supplies resources for thinking modes of community whose actualisation, albeit fleeting and permanently in need of renewal, does not betray some fundamental law through the reduction of the common to a specific property but resists that reduction by showing how the common remains open to all (Rancière, 2007, p. 90). ${ }^{18}$ Rancière's cases explore how subjects exploit immunitary laws or sanctions to highlight the improperness of the state's sense of what is proper.

Rancière's de-ontologised approach, however, does not simply supplement Esposito's philosophy: it also benefits from being framed by it. To develop Ranciere's thinking, to 
recontextualise it, Chambers (2013) suggests, 'may require a degree of commitment to ontopolitical interpretation greater than Rancière himself would allow' (p. 21). Esposito’s exposition of the ontological incompatibility of the common and the proper underlines the significance of Rancière's attempt to record those moments when communities already begin living beyond the proprietary paradigm. Rancière's subjects act on the presupposition that community includes anyone and everyone but, beyond the equality on which, he argues, any social order rests, he does not explain further the basis for this presupposition. Esposito lends support by analysing how its proprietary form suppresses community. Rancière would, however, reject Esposito's transformation of that assumption into a fundamental law. Such a move risks, he believes, ontologically privileging improper communities over proper ones. Improper communities, as the demonstration of equality, confront the dominant order on the same ontic plane; they are not supported by any fundamental law, remaining in constant need of verification. My claim is not that Rancière must ontologise community to ground his politics. ${ }^{19}$ It is his refusal to do so which shifts attention from philosophical redefinition favoured by Nancy and his followers to political praxis. Rather, I claim that Esposito's philosophy illuminates why community requires rethinking in terms of impropriety and how Rancière's politics provides a striking alternative to the mainstream philosophy and politics of community which annul it in their attempt to grasp it as a property.

\section{The Proper}

For Rancière, any social or, to use his words, police order is concerned with the proper, insofar as it distributes roles, functions and parts according to the assumed properties of the groups and individuals identified as belonging to community (Rancière, 1999, pp. 29-35). The proper, for Rancière, refers not simply to property as a quality and possession but also to 'a mode of decorum or a normative system for the assignment of persons in places and times' (Panagia, 2018, p. 7). This signification underlies his account of improper community as an 
act of reassignment or redistribution which reveals the contingency of that system. The police determines the proper, deciding who is perceived as fit to decide on common matters. Rancière names this process the partage du sensible. This term plays on the double meaning of partager of sharing and partitioning. This play recalls Esposito's idea of condivisione: sharing always involves division for any limits that separate us also connect us (Esposito, 2010, p. 139). However, for Rancière, that sharing/dividing is not a transcendental condition but socially produced when the police authorises certain people to partake in community while excluding others (Rancière, 2010, p. 36). His take on partager underlines its two-fold political implication: it provides the condition both for the hierarchical division between those qualified to rule and those disqualified and for its overturning. No division is purely divisive, Panagia asserts (2018, pp. 30-31). The line it establishes is shared by both groups, creating a point of contact which enables the partaking of those excluded from its distribution of roles and parts.

The police hierarchy stabilises itself by denying the double sense of partager: it creates both the impression of division without sharing by claiming a definite line between members and non-members and of sharing without division through the image of a community without remainder. Politics reveals the wrong of this impression when the improper community divides the police community from itself by sharing in it. The potential for this event is internal to the order it disrupts. The police's appearance of propriety holds only if everyone understands their place within it and behaves accordingly. This need for the equal capacity for understanding subverts from within the inequality on which regimes rest (Rancière, 1999, p. 16). That capacity gets verified politically when those without qualification for government govern themselves, when they demonstrate that there is no-thing that authorises the current power balance. 
The improper community transforms equality into political freedom as its members refuse to act in accordance with their allotted position. Freedom constitutes an 'improper property'. It is 'proper' to the people who, far from forming a pre-given category, get retrospectively and intermittently constituted when 'those who are nothing purport that their group is identical to the whole of the community' by proving their equality with it. It is 'improper' or 'empty', coming from the absence of any essential property which liberates individuals to contest the prevailing distribution of the sensible (Rancière, 1999, p. 123). It belongs to the demos because its exercise requires no specific properties or qualifications. Its impropriety thus makes it proper to anyone and everyone. Rancière would therefore agree with Esposito that freedom is not a quality or a possession and that it exists only as liberation not as a state. But he would not accord it any ontological value for the same reason he refuses to ontologise community. Like community, freedom must be verified through politics: it has no pre-political form. It gets enacted through the refusal to obey the hierarchical rules of propriety, through proof of the equal capacity of all which thwarts the police order's drive to slot bodies into pre-given categories and roles. While, for Esposito and Rancière, freedom occurs to interrupt immunising practices, Rancière examines how that interruption could arise. $^{20}$

\section{The Improper}

Rancière's politics, as the disordering and reordering of society by those without proper part in it, opposes its conventional meaning as the set of institutions and procedures which organise community into its constituent parts. This function, which seeks to define what is common, is reserved for the police. Rather than representing an ontological openness, the common, for Rancière, is always historically and socially determined, falling to subjects to dispute that determination through actions which verify its openness. The improper community of the part without part fulfils this role, interrupting the police's immunising 
operation by appearing where it does not belong, by intervening in affairs that do not concern it. 'Political impropriety is not not belonging: it is belonging twice over: belonging to the world of properties and parts and belonging to the improper community, to the community that the egalitarian logic sets up as the part of those who have no part' (Rancière, 1999, p. 137). Esposito's idea of impropriety as shared non-belonging affirms how community theoretically belongs to everyone but never explains how a particular community's sense of propriety gets affected by this condition. How do those that find themselves disqualified from the common demonstrate to its alleged proprietors that it cannot be owned without becoming its opposite? Furthermore, if immunitas and communitas are interdependent, is it politically effective to insist on an ontological lack of belonging given that ontically there are always borders between those that belong and those do not?

Rancière's approach to impropriety may offer some answers. His politics does more than deconstruct the proprietary logic, showing how the excluded turn their exclusion into a common concern. That the improper community does not occupy some transcendental sphere of non-belonging but belongs twice over is essential for revealing politically the coimplication of improper and proper. That revelation occurs when the uncounted make themselves count through a dispute which exposes the division from which the proper community acquires its sense of unity and its equality with those it has divided off. It redistributes the sensible by proving the co-existence of community and non-community. Rancière's analysis of the case of Rosa Parks illuminates this paradox (Rancière, 2006, pp. 61-62). Her improper behaviour of refusing to give up her seat at the front of the bus to a white passenger verified that she, like any other citizen, already had the right denied her as a Black American to sit where she wanted on public transport. To disrupt the sense of propriety, she could not simply protest about her lack of belonging: this would expose her exclusion without challenging it. Rather she had to demonstrate that she belonged to two 
communities at once: to the improper community of the part without part and to the community of equal parts. She made the fact that she did not count politically count as a shared wrong by proving the equality of anyone and everyone that disputes any society's rules of adherence. That proof created dissensus, revealing how the improper and the proper community already shared one world despite attempts to immunise one against the other.

\section{The Strategy of Testing the Common of Community}

Rancière's improper community intervenes in an existing community rather than transcends it. However, like Esposito's community, it is concerned with the in-between but not as an a priori openness conditioning all relations but as the intervals between identities and roles, between the places socially assigned to individuals and the ones they choose to occupy transgressively, between bodies and their signification (Rancière, 1999, p. 137). The inbetween, for Rancière, gets politically produced when subjects, like Parks, expose the gap between their equal capacity to act in the name of the common and their unequal treatment as the part without part. While Esposito stresses how ontologically we all equally share in the world, Rancière's politics highlights how ontically not everyone's share is equal. His analysis of this inequality supplements Esposito's reflection. Experiencing the common in nonproprietary ways would entail first perceiving and challenging the wrong of its appropriation. That challenge, for Ranciere, occurs when subjects live as if the common is already open in a context that has tried to enclose it not to falsify a society's claim to commonality but to verify it with deeds. These acts of subjectivation do not create 'ex nihilo' subjects but transform 'identities defined in the natural order of allocation of functions and places into instances of experience of a dispute' (Rancière, 1999, p. 36). Whereas Esposito aligns the subject with the logic of the proper, for Rancière, subjects get constituted by disputing their proper place in society by thinking and acting beyond it, so that their name or classification no longer corresponds to its alleged property or part. 
To claim that Rancière's cases supplement Esposito's work by showing how communities experience their divisions as an attack on, rather than defence of, the common would require them to be more than isolated instances, to supply a strategy for defying propriety. Woodford has identified in Ranciere's cases three dissensual practices which trigger politics: appropriation, dis-identification and subjectivation. They disrupt rules of belonging by proving that anyone and everyone can partake of community whether they are authorised to do so or not. While politics cannot be planned or instituted, it can, Woodford argues, still be rendered 'more effective' and 'more available' through praxis. I follow her in questioning the view that the ruptural character of Rancière's politics leaves it offering little direction for how to attenuate or overcome the entrenched exclusions of institutional democracy which betray the democratic value of universal equality (Woodford, 2017, pp. 176, 29-60). Appropriation, dis-identification and subjectivation interrupt the reproduction of proper ways of being, acting or saying to disclose a community which makes itself count as equal to the police community despite being uncountable and of no account for it. Studying these practices indicates how the event of the improper community, albeit disruptive and unpredictable, could arise.

The case of Jeanne Deroin offers a useful example for examining these practices. Deroin had the audacity, in 1849 , to stand as a candidate for a legislative election in which she was not allowed to run. Her act of appropriating a right deemed proper to men demonstrated 'the contradiction within a universal suffrage that excludes her sex from any such universality' (Rancière, 1999, p. 41). Subjects, like Deroin and Parks, practise appropriation to prove that no right, action or domain pertain to a particular group or identity. It thus functions paradoxically not to declare ownership but refute any such declaration. It turns the proprietary logic against itself: if one group can claim rights, then anyone else can for the act of claiming is only possible because of the absence of any natural order. That 
absence enables democracy as the right to rule of anyone. Political appropriation differs from police appropriation in that it occurs without property in both senses (a quality that grants entitlement and possession). It enacts the expropriation constitutive of communitas for Esposito, revealing the double belonging of impropriety. On the one hand, Deroin's 'unseemly appearance', as a woman on the electoral stage, proved her right to participate like anyone else in elections despite being refused that right (Rancière, 1999, p. 42). On the other, its unseemliness exposed women's absence from the public domain, their lack of rights. This dissensual scene does not just protest the inconsistent application of the universal law: a simple protestation would reveal the inequality but would not challenge it. Rather, it demonstrates that universality with deeds that show that if the law is properly universal, it should already logically include women and therefore their exclusion is improper.

Her appropriative act draws a contentious line between the proper and improper: the proper place of woman - the domestic sphere - already partakes of what is improper to it, the public realm of law (Rancière, 1999, p. 41). Fundamental to the republic is 'the declaration of equality that does not recognise any difference between the sexes' and 'the idea of complementarity in laws and morals.' Women play the part of providing the moral education of future citizens. The domestic sphere is therefore at once 'a private space, separated from the space of citizenship' and a space included in 'the complementarity of laws and morals central to the realisation of good citizens' (p. 41). Deroin's actions prove how the republicans' attempt to immunise community already includes what it has excluded, how it attacks the principles it aims to uphold, by producing a particularised universality which refuses legislative agency to women despite their role as moral educators.

What makes Deroin's appearance a political event is its impropriety. That appearance should be insensible because women belong exclusively to the domestic sphere. Its noncorrespondence with the prevailing distribution of the sensible makes even more visible her 
declaration of the rights of those without rights, measuring the gap between the Republic's egalitarian principles and its hierarchical organisation. Rancière's politics is therefore not about recognising pre-given identity and interest groups who are then accorded what they are owed. If it were, it would do little to surpass democratic liberalism which, for Rancière, constitutes a particular police regime concerned with the proper distribution of rights and goods in accordance with predefined categories ${ }^{21}$ Liberalism's proprietary conception of rights, for Rancière, has nothing to do with democracy which, as the right to rule of anyone and everyone, operates beyond identities and classifications in an impersonal sphere (Rancière, 2010, pp. 62-75). The practice of appropriation provides a strategy for resisting that conception: subjects, like Deroin or Parks, by taking rights officially deemed not theirs, show how those rights belong to everyone and therefore cannot be owned and then granted by the state.

Appropriation is therefore used in an autoimmune fashion against the appropriative logic which, for Esposito, underlies the liberal idea of the private person as the proprietor of rights, in need of legal protection. Following Simone Weil, he highlights how the category of the person, far from communalising rights, has immunised them. That category has always been determined through exclusion: to be labelled a person, someone requires an attribute such as mastery over her body or the life of another that differentiates her from non-persons or things (Esposito, 2013b, pp. 112-21). If rights are the prerogative of the person, they exclude anyone or anything outside that category (Esposito, 2012, pp. 100-3). Personalisation renders 'a properly human right [...] conceptually impossible' (Esposito, 2013b, p. 116). Rancière's subjects, through unauthorised partaking, contest this assertion, proving how anyone can bypass state criteria for inclusion to prove their right to rights. In this sense, rights are not simply claimed, as Esposito assumes, but enacted in a way that respects the munus of community. 
Rights become common only by appealing to the impersonal anyone and everyone. While Esposito reviews philosophical 'moments' such as Blanchot's idea of the neuter or Deleuze's becoming animal to sketch an impersonal understanding of the person, Rancière, through his cases, highlights how the impersonal gets politically inscribed through the practice of appropriation (Esposito, 2012, pp. 105-51). That practice entails dis-identification which is essential for breaking the link between individuals and their assigned roles or identities. Disidentification could be read as transforming Esposito's idea of the expropriation of identity into a method of equality, involving the removal from 'the naturalness of a place, the opening up of a subject space where anyone can be counted since it is the space where those of no account are counted' (Rancière, 1999, p 36). It allows the impersonal to be inscribed through the production of new subjects who, by not fitting the categories available to the current sensory regime, suggest new ways of being, saying and doing. This sensory reconfiguration, engendered by subjectivation, is vital for challenging the proprietary organisation of community. If the equality of a certain group goes unrecognised, recognition would depend first on altering the prevailing conditions of recognisability. For example, before women's equality could be debated as a common issue, women such as Deroin sought to make its insensibility sensible within the order that had dismissed it. She behaved as if the impossible was already possible, as if she already belonged to the public domain despite being officially deprived of public agency.

Improper communities are constructed around dis-identification rather identification insofar as the unequal can demonstrate their equality to others only if they reject their subordination and partake of community despite having no part. Dis-identification allows subjects to surpass the world of properties, identities and roles to experience the impersonal equality that opens the common to anyone and everyone. What is significant about Deroin's case is not the verification of women's rights but the verification of the right of those without 
rights which distances the community from its sense of proper identity by counting the uncounted, by placing in common the uncommon. While she does not secure universal suffrage, she manages to rework the field of common experience by declaring the existence of a subject that disrupts the sensory regime of the official community. Her political subjectivity of in-betweenness resists police appropriation, exposing the figure of anyone and everyone which exceeds division and classification: "In politics "woman" is the subject of experience - the denatured, defeminised subject - that measures the gap between an acknowledged part (that of sexual complementarity) and a having no part' (Rancière, 1999, p. 36). The name woman no longer designates a 'collective identity' but a 'collective capacity to construct a new common' in which the community where women participate politically like anyone else breaks into the one where they do not (Rancière, 2016, p. 120). That 'demonstration of capacity is also a demonstration of community' (Rancière, 2007, p. 49). By affirming a world in which anyone can share, it proves to others their ability to occupy any role, position or place and thus modify or change the criteria for inclusion.

That shared world can inscribe itself within the police community only if it affects the self-perception of those who take their part for granted. They too would need to dis-identify with their sense of ownership of community to feel solidarity with the wrong of the part without part, to experience it as a common bond. Rancière analyses how the injustice of the French police's violent repression, in October 1961, of Algerians who had protested on the streets of Paris produced such a bond (Rancière, 1999, p. 138). The state felt so threatened by the fact that Algerians had appeared in public as political participants and as French citizens that it authorised violence against them in the form of beatings and drownings. Their erasure from the public sphere was twofold: not only were they violently suppressed or killed but there was no count of the dead bodies. This case not only indicates how acts of appropriation by the excluded or marginalised are so disruptive that they trigger violent expropriation and 
re-appropriation by the authorities to suppress any trace of their event. But, also, how that reappropriative act can backfire, causing another improper event that resists the police's attempt to restore propriety. The polemical community constructed around those uncounted bodies consisted not of identification with their victimisation or with the immediate cause of their protest. Neither of those responses would be political in Rancière's sense; neither would fundamentally dispute the State's policing of the borders between ours/theirs, common/ private, proper/improper. The common bond got constructed through 'a disidentification in

relation to the "French" subject who massacred them and removed them from any count'. To contest the authorities' attempt to immunise the public sphere, citizens had to enter into 'a litigious relationship' with their own citizenry (p. 139). They had to expose the gap between juridical citizenship which the authorities sought to protect by suppressing the protests by Algerians and political citizenship which opposed that suppression by holding the state to account for those they had refused to count officially (Rancière, 1998, p. 29). In that gap a community could emerge that was different from the one seen, named, and counted by the State and from the one for whom the State had assumed the Algerians were of no account. This political moment did not only entail disidentification but also an impossible identification with the count of the uncounted so that the miscount of the official community, its lack of accountability, could be experienced as a shared wrong.

\section{Conclusion}

For Rancière and Esposito, community is "not the realisation of a common essence or the essence of the common. It is the sharing of what is not given in-common' (Rancière, 1999, p. 138). Whereas Esposito seeks to uncouple the common and the proper to enable a radical rethinking of community, Rancière conceives a mode of politics which creates a contentious relation between them, where the line between proper/improper, common/private is constantly disputed through the partaking in community of those without part. Esposito calls 
for a rebalancing of communitas and immunitas through the creation of common spaces open to everyone and anyone. However, he never explains how that rebalancing could occur, how the existence of the common gets verified and acted upon in a context shackled by the proprietary logic. It is for this reason that I have supplemented his work with Rancière's. His improper communities tests Esposito's idea of communitas by counting the uncounted, by placing in common the uncommon. This appearance of the part without part interrupts the police's attempt to immunise community against subjects who do not fit its (ac)count of the common parts and parties. It uncovers the division at the heart of unity, the impropriety of the proper, the otherness within that opens any community to being reconfigured by those it has excluded or marginalised. Esposito understands the improper as alterity and therefore underlines both the risk and chance it represents: if something is other, we cannot predetermine its identity. Rancière, by linking it to the equality which inheres in, but also disrupts, social orders, affirms its potentially democratising effects. Improper communities reveal, expand, and revitalise community by creating new spheres of common experience, by demonstrating to others their equal capacity to make themselves count, by revealing a shared world between members and non-members. Challenging the proprietary logic does involve demonstrating the incompatibility of the proper and the common, as Esposito insists, but that demonstration depends on individuals who are willing to live as if the common is already open in a community that has tried to enclose it. Esposito's munus - the obligation and gift towards others - could be understood as this willingness to transgress exclusionary immunising practices in a bid to verify the openness of community, to prove its resistance to any proper form or identity.

I wish to thank the anonymous reviewers of $C P T$ and Mairéad Hanrahan for their invaluable comments on this article.

${ }^{1}$ This rethinking of community, initiated in 1983 by Nancy's Inoperative Community, sought to answer the urgent question of what remained of the communist ideal of a community beyond social divisions after the 
waning of communist states and the rise of neoliberalism. For the intellectual and historical context of Nancy's essay, see Balibar (2014). For a discussion of community in Nancy, Agamben and Esposito, see Greg Bird (2017) and Alexandros Kioupkiolis (2018).

${ }^{2}$ For a comparison of Nancy and Esposito on the proper, see Ignaas Devisch (2013a).

${ }^{3}$ For a discussion of this question, see Greg Bird and Jon Short (2013a).

${ }^{4}$ Bruno Bosteels (2010) also compares the work of Esposito and Rancière but in terms of their use of prefixes to qualify politics. Whereas Rancière uses archi, para, meta to describe how philosophy has 'erased, displaced, or given lie to the specificity of politics', Esposito employs im to designate the gap that thwarts the potentially totalitarian drive of militant politics (p. 12).

${ }^{5}$ The French impropre designates the incorrect use of language or grammar. The way politics declassifies, for Rancière, names so that they do not designate their assigned properties suggests this meaning.

${ }^{6}$ Esposito refers to Michael Sandel (1998) and Ferdinand Tönnies (2001). Ignaas Devisch (2013b) situates

Nancy and Esposito in relation to the American communitarians (pp. 6-37).

${ }^{7}$ For Esposito's critique of communitarianism, see Bird (2017, pp. 176-80).

${ }^{8}$ By contrast, Jon Short (2013) argues that Nancy's community transcends the alleged negativity of Esposito's. By affirming the singular value of each being, it enjoins us to become political subjects that oppose homogenising and exclusionary politics.

${ }^{9}$ For Esposito (2011), the Hobbesian state initiates the modern immunitary paradigm. State sovereignty operates to immunise individuals against the risk of community by subjecting them to the sovereign whose power of life and death protects them, in an autoimmune fashion, against their equal power to kill one another (pp. 86-7).

${ }^{10}$ Penelope Deutscher (2013) contrasts Esposito's account of autoimmunity to Derrida's, arguing that Esposito turns to an 'ideal image of community' to forestall immunitary excesses, whereas Derrida warns that we cannot secure 'positive alternatives to the dangers of immunisation' (pp. 62, 63). She overlooks Esposito's insistence on the autoimmunity of communitas.

${ }^{11}$ Esposito's biopolitics opposes the purely negative valence it assumes in Agamben (1998) as the production of bare life, as ultimately thanopolitics. For Esposito's contribution to biopolitical studies, see Catherine Mills (2018, pp. 89-107).

${ }^{12}$ Esposito (2013b) cites Nazism as an extreme example of how immunisation can produce 'an absolute convergence' between 'the protection of life and its negation.' The life of the superior German people, as the proper human community, had to be protected by sacrificing the life of inferior peoples. Sacrifice turned into self-sacrifice: near defeat, Hitler ordered the complete destruction of German infrastructure to prevent its appropriation by the opposition. The ultimate act of self-defence was self-annihilation (p. 73).

${ }^{13}$ Esposito (2011, pp. 169-171) offers the figure of the mother-embryo relationship as an example of affirmative immunity that tolerates alteration.

${ }^{14}$ Esposito's remark that 'there are currently no legal statutes and codes that protect the common in relation to the private, the proper and the immune' implies the public sphere could play an important role in defending the newly created common spaces (Esposito, 2013a, p. 89).

${ }^{15}$ Esposito (2013a) fleetingly cites the struggles over the planned privatisation of water, energy resources and 'the patents granted by pharmaceutical companies which prevent the distribution of cheaper medicines to poorer areas of the planet' (p. 89).

${ }^{16}$ For Rancière's rejection of ontology, see Samuel Chambers (2013, pp. 18-21).

${ }^{17}$ Nancy $(2007$, p. 526) accepts the criticism that being-in-common is not immediately political.

${ }^{18}$ For the renewal process, see Kevin Inston (2017).

${ }^{19}$ For Oliver Marchart (2011), Rancière's politics involves an "“ontological” form of an-archism' because universal equality comes from the groundlessness of any form of rule. Rancière risks, he argues, ontologically privileging egalitarian over non-egalitarian politics (pp. 136-137). While Rancière sees 'the egalitarian practice of philosophy' as enacting the 'aporia of foundation', he refuses to ground equality ontologically precisely to avoid the risk identified by Marchart. Equality, without ontological guarantee, remains a supposition to be verified through action (Rancière, 2011, p. 15).

${ }^{20}$ Esposito (2013b) describes freedom as 'the part of community that resists immunisation, that is not identical to itself' (p. 56).

${ }^{21}$ For a discussion of Rancière and liberalism, see Todd May (2008). 


\section{References}

Agamben, G. (1993) The Coming Community, Translated by Michael Hardt. Minneapolis: Minnesota University Press.

Agamben, G. (1998) Homo Sacer, Translated by D. Heller-Roazen. Stanford: Stanford University Press.

Balibar, E. (2014) Nancy's Inoperative Community. In V. A. Conley \& I. Goh (eds.) Nancy Now. Cambridge: Polity.

Bird, G. (2017) Containing Community: from Political Economy to Ontology in Agamben, Esposito, and Nancy. New York: SUNY.

Bird, G. \& Short, J. (eds.) (2013a) Roberto Esposito, Community and the Proper. Angelaki $18(3)$.

Bird, G. \& Short, J. (2013b) Community, Immunity, the Proper. Angelaki 18 (3): 1-12.

Bosteels, B. (2010) Politics. Infrapolitics, and the Impolitical: Notes on the Thought of Roberto Esposito and Albert Moreiras. The New Centenial Review 10 (2): 205-238.

Chambers S. (2013) The Lessons of Rancière. Oxford: Oxford University Press.

Derrida, J. (1995) On the Name, Translated by D. Wood. Stanford; Stanford University Press.

Deutscher, P. (2013) The Membrane and the Diaphragm. Angelaki, 18 (3): 49-68.

Devisch I. (2013a) How (not) to Properly Abandon the Improper? Angelaki, 18 (3): 69-80.

Devisch, I. (2013b) Jean-Luc Nancy and the Question of Community. London \& New York: Bloomsbury.

Esposito, R. (2010) Communitas: The Origin and Destiny of Community, Translated by T. C. Campbell. Stanford: Stanford University Press.

Esposito, R. (2011) Immunitas, Translated by Z. Hanafi. Cambridge: Polity.

Esposito, R (2012) Third Person, Translated by Z. Hanafi. Cambridge: Polity.

Esposito, R. (2013a) Community, Immunity, Biopolitics, Translated by Z. Hanafi. Angelaki 18 (3): 69-80.

Esposito, R. (2013b) Terms of the Political. Community, Immunity, Biopolitics, Translated by R. Welch. New York: Fordham University Press.

Inston, K. (2017) Inscribing the Egalitarian Event: Jacques Rancière and the Politics of Iterability. Constellations, 24 (1): 15-26. 
Kioupkiolis, A. (2108) Commoning the political, politicising the common: Community and the common: Community and the political in Jean-Luc Nancy, Roberto Esposito and Giorgio Agamben. Contemporary Political Theory 17 (3): 283-305.

Marchart, O. (2011) The Second Return of the Political: Democracy and the Syllogism of Equality. In P. Bowman and R. Stamp (eds.) Reading Rancière. London \& New York: Continuum.

May, T (2008) The Political Thought of Jacques Rancière. Edinburgh: Edinburgh University Press.

Mills, C. (2018) Biopolitics. London and New York: Routledge.

Nancy, J-L. (1991) The Inoperative Community, Translated by P. Connor et al. Minneapolis: Minnesota University Press.

Nancy, J-L. (1992) La Comparution/The Compearance. From the Existence of 'Communism' to the Community of 'Existence', Translated by T.B. Strong. Political Theory 20 (3): 371-398.

Nancy, J-L. (2000) Being Singular Plural, Translated by R. D. Richardson, A. E. O’Byrne. Stanford: Stanford University Press.

Nancy, J-L. (2007) Nothing but the World: An Interview with Vacarme. Rethinking Marxism, 19 (4): 521-535.

Panagia, D. (2009) Improper Event: On Rancière's Mannerism. Citizenship Studies, 13 (3): 2009, 297-308.

Panagia, D. (2018) Rancière’s Sentiments Durham: Duke University Press.

Rancière, J. (1998) The Cause of the Other. Parallax, 4 (2): 25-33.

Rancière, J. (1999) Dis-agreement: Politics and Philosophy. Minneapolis: University of Minnesota University Press.

Rancière J. \& Noudelmann F. (2003) Entretien avec Jacques Rancière: La communauté comme dissentiment. Paroles, 42: 86-99.

Rancière, J. (2006) Hatred of Democracy, Translated by Steve Corcoran. London: Verso.

Rancière, J. (2009) A Few Remarks on the Method of Jacques Rancière. Parallax, 15 (3): 114-123.

Rancière, J. (2010) Dissensus on Politics and Aesthetics, Translated by Steven Corcoran. London: Continuum.

Rancière, J. (2011) The Thinking of Dissensus: Politics and Aesthetics. In Paul Bowman and Richard Stamp (eds.) Reading Rancière. London and New York: Continuum. 
Rancière, J. (2016) Methods of Equality: Interview with Laurent Jeanpierre and Dork Zabunyan, Translated by J. Rose. Cambridge: Polity.

Sandel, M. J. (1998) Liberalism and the Limits of Justice. Cambridge: Cambridge University Press.

Short, J. (2013) On an Obligatory Nothing: Situating the Political in Post-metaphysical Community. Angelaki 18 (3): 139-154.

Tönnies, F. (2001) Community and Civil Society, Translated by J. Harris \& M. Hollis. Cambridge: Cambridge University Press.

Woodford, C. (2017) Disorienting Democracy: The Politics of Emancipation. London: Routledge. 